\title{
TRYING TO FIX ROOTS IN QUICKSAND: SOME DIFFICULTIES WITH WALUCHOW'S CONCEPTION OF THE TRUE COMMUNITY MORALITY
}

\author{
Noel STRUCHINER* \\ Fábio Perin SHECAIRA**
}

Resumen:

Los defensores y oponentes de la figura del judicial review que se lleva a cabo a través de la defensa de las garantías individuales en ocasiones comparten puntos de vista en relación con los ideales políticos, sin embargo, existen profundos desacuerdos en cuanto a la mejor forma de promocionarlos o en cuanto a la manera apropiada de decidir casos concretos en casos de conflicto. En su más reciente libro, Wil Waluchow intenta proporcionar una teoría del judicial review que atienda adecuadamente los ideales comunes de estabilidad y adaptabilidad. El punto medular de su argumento es la noción de la moralidad de la comunidad - aquella que permite a los jueces constitucionales desarrollar las garantías y derechos (adaptabilidad) mientras que se continúa leal a los principios de democracia y Estado de derecho (estabilidad)-. El objetivo de este trabajo es ofrecer una crítica a esta noción de moralidad de la comunidad, concretamente el objetivo es plantear un reto a la cuestión de asumir que la moralidad de los miembros de las sociedades modernas plurales es tan uniforme como lo exige la teoría de Waluchow.

* Professor of Law and Philosophy, Pontifical University of Rio de Janeiro (PUC-Rio). I would like to thank FAPERJ (Primeiros Projetos), MCT/CNPq, and CAPES for funding my research. I would also like to thank Dina Thrascher and Paul Brunet, from the Canadian Consulate General, for making Wil Waluchow's visit to Rio possible. We are especially grateful to Waluchow for his kindness, availability, and openness for discussion during and after his lectures in Rio.

** Graduate student, Department of Philosophy, McMaster University. 
Palabras clave:

Moral de la comunidad, teoría del judicial review, razonamiento judicial, Wil Waluchow.

\begin{abstract}
:
Defenders and opponents of judicial review under charters of rights often share political ideals, and yet disagree deeply on the best means to promote them or on the proper way to balance them in the event of conflict. In his most recent book, Wil Waluchow attempts to provide a theory of judicial review which deals adequately with the popular ideals of stability and adaptability. The cornerstone of his argument is the notion of community morality - that which enables constitutional adjudicators to develop charter law (adaptability) while remaining loyal to democratic and rule of law principles (stability). The aim of this paper is to offer a critique of the notion of community morality; in particular, the aim is to challenge the assumption that the morality of the members of modern plural societies is as uniform as Waluchow's theory requires it to be.
\end{abstract}

Keywords:

Community Morality, Judicial Review Theory, Judicial Reasoning, Wil Waluchow. 
Wil Waluchow has recently offered an intriguing defense of judicial review under charters of rights. The core of his argument lies in a revision of a relatively widespread notion of the function of charters of rights in modern democracies. This is how Waluchow sums up his point: We should reject the view of Charters as confident, hubristic attempts to establish illusory fixed points of agreement and pre-commitment. We should view them instead as living trees whose roots are fixed by factors like precedent, the community's moral judgments in reflective equilibrium, and the terms it has chosen (in its Charter) to express the fundamental commitments of its constitutional morality (p. 270-271.) ${ }^{1}$

As the metaphor suggests, by its reference to living trees and fixed roots, Waluchow's central aim is to provide a theory of judicial review that balances the (frequently conflicting) ideals of adaptability and stability. A society evolves and so do its needs. This calls for occasional changes in its legal structure. But such changes should be realized within limits. For one, they should not be too fast or too deep or in any way too traumatic for the many individuals who rely on existing social norms. Also, they should not be based on individual whim, but should be subjected to constraints of democratic pedigree. According to Waluchow, a healthy balance between stability and adaptability is guaranteed by a theory of judicial review that allows judges to develop the law as established in charters of rights, but to do so incrementally and within the limits set by objective factors such as constitutional text, precedent and the community's (true) morality.

We have much sympathy for Waluchow's general project. We share the ideals he wants to serve through his theory (i.e. stability and adaptability), and we find his notion of the function of charters of rights much more appealing than

1 All page references in the text are to W. J. Waluchow, A Common Law Theory of Judicial Review - The Living Tree (Cambridge University Press, 2007). 
the popular, hubristic notion of charters as documents capable of establishing fixed points of pre-commitment. However, we have some worries about the details of Waluchow's theory. In particular, we worry that Waluchow is too confident about the guiding capacity of what he describes as the true morality of the community. ${ }^{2}$ In the passage quoted above, Waluchow refers to the morality of the community as one of the factors that help fix the roots of the living tree. As we understand this assertion, for the morality of the community to fix anything it must be genuinely actionguiding, that is, it must provide prescriptions precise enough to limit the discretion of judges adjudicating under a charter of rights. For if the morality of the community does not really guide action, then the talk of its fixing roots is misleading. And if the talk of fixing roots is misleading, then Waluchow's crucial contention that his theory adequately serves the value of stability becomes implausible.

2 Even though we will not discuss this much in the paper, we should point out that we are equally sceptical about the possibility of precedents and word choice being capable of fixing roots. This is not to say that we do not believe in the firm guiding capacities of precedent and word-meaning. As Hart, we agree that both forms of communicating directives can be effective. In a community where language meaning is taken seriously, both precedents and explicit rule-like mandates can constrain decisions in cases that fall under their core meanings. But also in accord with Hart, we think that these strategies for establishing standards of conduct that can be followed without further considerations in many situations can nevertheless generate indeterminacies due mainly to ab initio vagueness or potential vagueness (open texture). When the language of precedent or charters does not constrain because of long standing vagueness or concretized potential vagueness then we are in the realm of hard cases, the cases that fall under a penumbra of doubt. Many of the cases that call for judicial review under charters (perhaps most of them) are cases where the conventional meaning of the language of both precedents and charters will not dictate a clear answer and therefore will not fix roots. As we understand Waluchow's proposal, the true morality of the community is the only means available (i.e. acceptable) for filling in the pores of the relevant constitutional norms. In some cases, one of which will be discussed later in the paper, the true morality of the community might even be capable of dislodging well established precedents or well established interpretations of charter language. That is why we will focus on community morality: the viability of Waluchow's proposal is highly dependent on the viability of this notion. 
We are not the first to find serious problems in Waluchow's notion of community morality. Several commentators have already questioned his confidence in its capacity to constrain judicial reasoning and decision-making. ${ }^{3}$ Therefore, our objections won't be entirely novel, but they should make the case against community morality even more compelling.

According to Waluchow, the community's true morality emerges once the moral opinions of the community have been subjected to a process of rational revision. This does not amount to rectifying the community's moral opinions in the light of one's preferred moral theory. For instance, a utilitarian judge, no matter how cogent his arguments in favor of utilitarianism, should not reshape the moral opinions of the community in order to eschew or mitigate its non-utilitarian tendencies. Instead, what a judge may do is take the community's moral beliefs (in all levels of abstraction) and make sure they are coherent among themselves. If the result of this process is a community morality that has a utilitarian feel to it, then that should be because the community's most fundamental convictions were already utilitarian to begin with, not because the utilitarian judge did his best to make them so.

Waluchow's description of the process of revision that should generate the true morality of the community is actually quite vague. He claims that it is "something like" (p. 223) John Rawls's reflective equilibrium, but does not say too much more about it. It does seem, however, that he has narrow reflective equilibrium in mind, as he never mentions the possibility of examining the community's background (sociological, psychological, metaphysical, etc.) beliefs in order to see if they cohere with their specifically moral beliefs. Waluchow also seems to hold the common view that reflective equilibrium goes naturally with a roughly coherentist moral epistemology. In other words, the firmly held moral

3 See Larry Alexander; Jeffrey Brand-Ballard; and Bradley W. Miller. 
convictions of the community, though they may have independent pro tanto credibility, can naturally be overridden or reshaped somewhere along the process of revision. There is not much more we can say about Waluchow's notion of reflective equilibrium, since, again, he is not very precise about this.

If we are right about Waluchow's views on reflective equilibrium, then his theory of judicial review under charters of rights runs into some problems. The first thing that comes to mind is that he overestimates the amount of agreement within communities on the type of moral question that arises in cases of judicial review under charters. To be sure, Waluchow is not claiming that the community frequently exhibits uniformity in all its (superficial) moral opinions regarding the sort of case that elicits judicial review. What he is actually saying is that there is sufficient uniformity regarding the community's true moral commitments pertaining to that sort of case. After the community's expectedly diverging moral opinions are put to a test of internal coherence, it is likely that a uniform position will emerge. In other words, lack of consensus in moral opinion does not preclude the likelihood of consensus regarding fundamental moral commitments.

While this qualification is enough to show that Waluchow's claim about consensus is not naive, it hardly shows that it is true. It remains to be shown that the existing consensus provides a wide enough base on which to build the community's true morality. In all fairness, it is not unreasonable to believe that, even in plural societies such as the ones Waluchow is concerned with, there is general agreement on many important moral questions. But there is really no reason to believe that the agreement is significant in the domain of moral debate that concerns us. It seems that Waluchow has to carry the burden of proof here - and it is a heavy burden to bear. ${ }^{4}$ To show that his confidence in the

4 We assign Waluchow the burden of proof because the empirical evidence seems to be on our side. The literature available on the idea of "culture wars" is al- 
significance of consensus is warranted, Waluchow should, at the very least, be capable of producing some (two? three?) concrete examples. But he does not succeed in that task: his examples are scarce and unconvincing. In fact, there is only one example which he discusses in detail:

...the principles and considered judgments upon which most reasonable Canadians, of whatever political and moral stripe, are keen to condemn racial bigotry and sexism and that virtually all would agree are embodied in the Charter and the jurisprudence surrounding its interpretation equally condemn prejudice against same-sex marriage. This despite the fact that many do not (yet, I hope) see this connection... (p. 225)

There are obvious problems here. For one thing, Waluchow does not explain what he means by "reasonable." If he holds a rich enough conception of reasonableness, then he may be jeopardizing his central claim that, in subjecting the community's moral opinions to rational revision, one is not rearranging it in light of one's own subjective moral beliefs. For it is one thing to say that the community's opinions should be made internally coherent, but it is quite another to say that the opinions of the reasonable

ready abundant. Recently, Jonathan Haidt and others have done much work in order to explain the divide on moral issues between liberals and conservatives. From a descriptive/explanatory point of view about how we come to have the moral belief sets that we do, he defends the "Moral Foundations Theory". According to this theory there are certain basic modes of response, certain learning modules or psychological mechanisms, shared by all human beings, which are prepared to react to five sets of patterns in the social world. He offers the following (tentative) taxonomy to try to capture these five basic response modes or moral foundations for the bases of moral judgments, intuitions, and concerns: harm/care; fairness/reciprocity; ingroup/loyalty; authority/respect; purity/sanctity. While liberal moralities are empirically demonstrable to hinge upon preoccupations with harm and fairness, conservatives' moral concerns are distributed more evenly across all five foundations. These considerations, if correct, explain why liberals and conservatives have such divergent profound moral commitments in relation to many issues which cannot, at the moment, be reconciled with each other through the method of narrow reflective equilibrium. We believe that narrow reflective equilibrium would require factoring in both the moral views of conservatives and liberals and no true homogeneous moral commitments would emerge in most, even if not all, cases that occupy our attention when we discuss judicial review under charters. 
members of the community should be made internally coherent. Coherence is not a morally loaded concept, but reasonableness is. Indeed, it can be a very rich moral concept, excluding any moral opinion that fails to satisfy strict criteria; or it can be a more modest concept, that is, one that only excludes grossly implausible (though internally coherent) moral views. ${ }^{5}$

Let us assume that Waluchow uses a modest notion of reasonableness. ${ }^{6}$ In this case, if all moral views that are not

5 To be sure, both concepts, rich or modest, present problems due to their vagueness and subjectivity. But as the modest notion is arguably less vague, one might say that the problems it poses are, accordingly, less significant. The difference between the two may be illustrated by some quips picked up from Kwame Appiah's (2008) discussion of a closely related issue. A rich notion of reasonableness is very likely to be controversial in a plural society. And similarly, the constitutional adjudicator's notion of reasonableness is likely to be regarded with suspicion by any dissenting Canadian. Any attempt by the adjudicator to base a decision on what "we, reasonable Canadians, believe" should be met by dissenters with the following complaint: "What do you mean 'we,' Kemo Sabe?" (Appiah, 2008, p. 80). The use of a modest notion of reasonableness might not provoke such an uncongenial response, but it should also raise some eyebrows. For who has the authority to say that a moral opinion relative to a charter case is grossly implausible? Is it the kind of thing that is just obvious? Here Appiah tells a story of a Cambridge mathematician who after having filled the chalkboard of his class with a vast and intricate equation, underlined the result for the equation and told his class: "As you can see, it's obvious." However, he was taken by a sudden doubt, and, with a furrowed brow, left the room, only to return five minutes later. Upon his return, demonstrating to be in fine spirits and no longer worried, he assured his student: "Why, yes, indeed, it is obvious." (Appiah, 2008, p. 81).

6 Again, this assumption assuages our worry about Waluchow's introduction of the concept of reasonableness in the debate, but it does not dispel the worry entirely. The problem we see is not limited to the fact that even a modest concept of reasonableness is too vague to constrain judicial decision-making (this point is made in the ensuing part of the text). More fundamentally, we do not know how to reconcile Waluchow's isolated reference to reasonableness with the rest of his book. In one particular passage he describes his theory - in terms borrowed from Julie Dickson - as "indirectly evaluative" (p. 227). Waluchow then goes on to say (or rather reaffirm) that his theory is not capable of rectifying a community morality when it is fundamentally deplorable; and he gives apartheid South Africa as a historical example. Well, it is pretty clear from these claims that Waluchow's theory is not designed to transform an unreasonable community morality into a reasonable one. But if that is the case, why the reference to reasonableness at all? Appiah has said that the method of reflective equilibrium (at least in its narrow version) can do no more than give our extant moral opinions a haircut and a shave (Appiah, 2008, p. 80). Waluchow seems to agree with this in most of his book, but then he talks about reasonableness and gives us as a surprising picture of an adjudicator that 
grossly implausible are really taken into account in the process of rational revision, then Waluchow's confidence in a convergence of the Canadian community around same-sex marriage is unwarranted. There is no reason to think that one cannot (in Canada or elsewhere), reasonably and coherently, endorse moral principles that reject racism and sexism, and yet take the view that same-sex marriage should not be a legally valid institution. To begin, one's position on the morality of a legal norm does not necessarily mirror one's view about the morality of the individual acts covered by the norm. For instance, one may find abortion morally objectionable, and yet oppose an anti-abortion law. This is quite common among people who tend to evaluate social institutions in a consequentialist fashion. While abortion may be wrong, the effects of its prohibition (e.g. the probable proliferation of "back-alley" abortions) may be even worse. The same applies to same-sex marriage. Someone might favor laws against racial and sexual discrimination, and perhaps even support laws recognizing basic rights to samesex couples, and yet believe that same-sex marriage is a dangerous institution, as it would be a large step towards, say, the legalization of the adoption of small, psychologically vulnerable children by same-sex couples. This particular line of argument may seem unconvincing to many (as it does to us), but it is hardly unreasonable. To exclude it from the base of agreement upon which the true morality of the community is to be built is to interfere in the community's opinions in a way that Waluchow's theory should not allow (if it indeed wishes to limit judicial discretion).

Another way to challenge Waluchow's confidence in the consensus of Canadians regarding same-sex marriage is as follows. If we take the coherentist model of reasoning that underlies Waluchow's argument seriously, then we should acknowledge that none of the moral beliefs that are put to the test of internal coherence are immune from revision.

wants to do a lot more to the morality of the community than what a regular barber would. 
Canadians who firmly reject racism and sexism may have an equally firm moral conviction in the value of traditional, heterosexual marriage. And to accommodate the latter conviction they may be willing to make changes elsewhere in their belief set. When considering the implications of their views on marriage, they might even wish to go back and reevaluate their prior commitment to beliefs on racism and sexism. To elect certain convictions as non-revisable would be to, arbitrarily, transform a coherence model of reasoning into a foundationalist one - wherein the relevant foundations are chosen not by the community but by the judge!

Now, Waluchow probably would want to make a reply at this point. He would want to criticize us for inappropriately editing his argument. We should not have cut short the passage quoted above with a sneaky ellipsis. The passage continues:

This despite the fact that many do not (yet, I hope) see this connection and will perhaps not do so unless it is pointed out to them by some other party, perhaps the Supreme Court in a landmark ruling. (p. 225, no italics in the original)

Indeed, the part left out before is not irrelevant. Waluchow is very explicit about the fact that precedent is a key element in the construction of the morality of the community (p. 237). In addition to the consensual moral convictions of the community, legal precedent also contributes to widen the base upon which a uniform community morality is to be built. However, we see two reasons why this appeal to precedent is not as helpful as it may seem. First, in accordance with the coherentist model we have been assuming, precedent, like any other moral belief, is overridable. In order to accommodate a firm moral conviction (whether it concerns same-sex marriage or not) one may be happy to reject a precedent whose implications do not cohere with that conviction. Second, and more fundamentally, it is seriously misleading to suggest that precedent can be a part of the morality of the community when contro- 
versial moral issues are concerned. Citing Tony Honoré and Joseph Raz (p. 233), Waluchow talks about how community morality is but an outline whose missing details should be filled in by legal judgments. Well, the metaphor is apt, but not for all of Waluchow's purposes. In those areas where morality is genuinely indeterminate, it is indeed sensible to say that legal judgments may legitimately offer assistance. That is, when the consensual moral commitments of the community would equally allow any one of a couple or several different measures, the one chosen by legal officials, for reasons related to efficiency and predictability, should govern. But where the community is not indifferent, but in fact deeply divided, law's function as a gap-filler is highly debatable. It seems to us that when (for instance) a judge chooses to allow same-sex marriage in a community that differs on the morality of this institution, he is not simply "filling in" a detail; he is in fact taking sides and validating the commitments of a part of the community, in spite of the commitments of the other part (which may be no less numerous or reasonable than the first).

These are the objections we are prepared to make regarding one of Waluchow's rare examples of uniformity in the moral commitments of plural societies. But there is a further, and final issue that arises from the consideration of a case about which, this time, Waluchow concedes that it is very unlikely that a plural society will agree.

Indeed, on some highly contestable questions, for example questions concerning the morality of abortion, there may be no overlapping consensus, implicit or otherwise. If so, then the community's constitutional morality will fail to provide determinate answers in Charter cases, and judges will have to draw upon other resources... (p. 228-229).

One wonders why Waluchow would think that abortion does not admit of consensus where same-sex marriage does. 
Both issues are equally controversial in plural societies, at least when unrevised moral opinions are concerned. Waluchow cannot be saying this just because the participants in the debate about abortion, whatever their other moral beliefs, are not prepared to give up their individual views about abortion. For this is precisely one of the reasons why we think there can be no consensus on same-sex marriage: under a coherence model of reasoning, no belief enjoys absolute credibility. Another reason why Waluchow may see abortion as such a divisive issue is that debate about abortion can hardly avoid reference to issues even more complex and puzzling than moral issues. When does life begin? How conscious is a fetus, if at all? (Not to speak of the religious questions typically elicited.) But this would lead us down a path that is not consistent with what was said earlier in the paper. Waluchow suggests that a revision of the community's moral beliefs should be done in accordance with the method of narrow reflective equilibrium, that is, a method that attempts to produce a coherent moral theory, but ignores the (in)coherence of such a theory with one's metaphysics, for instance. This final point should be understood not so much as an objection to but as the expression of a genuine doubt about Waluchow's notion of true community morality and the method that yields it. If he really has narrow reflective equilibrium in mind, then why wouldn't abortion possibly be an object of consensus, whereas same-sex marriage would? This really isn't clear in Waluchow's work. It is an important point though, because understanding why he believes there cannot be agreement on some cases, might help us have a better grasp of why he thinks there can be agreement in other, equally disputed cases.

In a final note, there is no doubt that Waluchow is a meticulous legal thinker not accustomed to leaving loopholes in his work. As was said earlier, we are very sympathetic to his general project of finding a middle ground between the virtues of stability and flexibility. But until he can demonstrate, in clear light, how the method of narrow reflective 
equilibrium can tease out the true moral commitments of a deeply divided community, we will continue believing that the "Living Tree" has its roots fixed in quicksand.

\section{REFERENCES}

AlEXANDER, L., "Waluchow's Living Tree Constitutionalism", Law and Philosophy, Published online, 09 June 2009.

APPIAH, K. A., Experiments in Ethics, Cambridge, Harvard University Press, 2008.

BRAND-BALlaRD, J., "Review Essay: A Common Law Theory of Judicial Review by W.J. Waluchow", Notre Dame Philosophical Reviews. Available at http://ndpr.nd. edu/review.cfm?id=14605 (2008.11.05).

HAIDT, J. \& Joseph, C., "The Moral Mind: How 5 Sets of Innate Moral Intuitions Guide the Development of many culture-specific virtues, and perhaps even modules", in CARRUTHERS, P., LAURENCE, S., and STICH, S. (eds.), The Innate Mind, vol. 3 (New York, Oxford University Press, 2007).

Graham, J., HaidT, J., \& NoseK, B. A., "Liberals and Conservatives Rely on Different Sets of Moral Foundations", Journal of Personality and Social Psychology, vol. 96, N. 5, 2009, 1029-1046.

Miller, B. W., "Review Essay: A Common Law Theory of Judicial Review by W. J. Waluchow". The American Journal of Jurisprudence, vol. 52, 2007. Available at SSRN: http://ssrn.com/abstract $=1093365$.

Waluchow, W. J., A Common Law Theory of Judicial Review - The Living Tree, Cambridge, Cambridge University Press, 2007. 